\title{
An Applied Valuation of the Association among Internal and External Auditors
}

\author{
Dr. Alhassan Haladu, ***Mohammed Haliru Beri \\ Department of Accounting, Faculty of Social \& Management Sciences, Yusuf Maitama Sule University, Kano \\ ***Department of Accountancy, School of Management Studies, Kano State Polytechnic, Kano State Nigeria.
}

\begin{abstract}
The study examines the cooperation between internal and external auditors in discharging duties and upholding organizational objectives. The aim is to know how the internal auditor relates with the external auditor once appointed and especially during the process of carrying out his/her duties. To achieve this primary data was collected through face-to-face interview from Mike Ukueje \& Co. which is the case study of this research. The result showed that both the internal auditor and external auditor work in the interest of the organization through emphasis on the internal control system even though they are guided in their duties by the articles of association (internal auditor) and CAMA 2004 (external auditor). In the private sector external auditors are welcome whole heartedly by their internal counterpart, while in the public sector they are treated with suspicion and prejudice. For this reason it is advisable to enlighten the public sector more on the responsibilities of the external auditor.
\end{abstract}

Keywords - internal auditor, external auditor, audit test, content report

\section{$1 \quad$ Introduction}

The last five hundred years marks the period of discoveries and inventions which has led to a tremendous development in Accounting (Anao, 1989). The economic organizations that sprang up to exploit such discoveries need to secure accountability to owners of resources. The need therefore, for Accountants (Auditors) to monitor, supervise and report the operations of such organizations was inevitable. In Nigeria, the Companies and Allied Matters Act (CAMA, 2004) makes it mandatory for all organizations to have external auditors. These external auditors found it necessary to work with their counterparts (internal auditors) in organizations so as to attain the overall objective of accountability. Accountability will be better achieved if a cordial and healthy relationship exists between the Auditors. However, it sometimes happens that such relationships are bedevilled by suspicions and hatred (Mike, 2011) which have the result of an overall negative impact. Poor relationship between the internal and external auditors is one problem greatly affecting accountability in Nigeria today (Anderson, 1998). Any case of connivance or disagreement between them may smack the whole economy in the face. We have witnessed how bad accounting services have caused multinational corporations like Enron, Parmalat, and even African Petroleum Nigeria Plc. to pay a very high price. The 2008 world economic recession and the US Housing scandal (Sheka, 2009) cannot be dissociated from improper accounting services.

In a developing economy like Nigeria poor accounting services will have a serious effect on the economy. The fact that the internal auditor was in charge before the coming of the external auditor makes him strongly bound to the external auditor. It is this bond and relationship as it is expected to operate in Kano metropolis that was examined in this paper. It is therefore, the intention of this paper to examine at the working partnership that exists between accounting firms and internal auditors. The aim is to make a thorough analysis and find out the impact such relationship is having on services rendered. For this reason, the researcher restricted this investigation to Mike Ukueje and Co. and assess the firm's relationship with the internal auditors of organizations it had served within Kano Metropolis. The degree of cooperation between the two in terms of discharging their duties and upholding the objective of the organization goes a long way in marking the success of any organization.

For the purpose of comprehension the study has been divided into five sections. The first is the introduction which spells out the background and objectives of the research. In the review of relevant literature an evaluation of literatures and previous researches on the relationships between the two was done to show gaps in the investigation. The methodology briefly discusses the basic tools of data collection and analysis. In the fourth part, a detail analysis was done on the case study. The final section is the conclusion bringing out the major findings and recommendations. 


\section{REVIEW OF RELEVANT LITERATURE}

\section{The Concept of Auditing}

As cited by Dandago (1999:15) International Auditing Guideline (IAG) defines Auditing as: "The independent examination of and an expression of opinion on, the financial statements of an enterprise by an appointed auditor in pursuance of that appointment and in compliance with any relevant statutory and professional obligations".

Auditing can also be seen as being:

"An autonomous assessment function set up by the administrators of a business entity for the evaluation of the internal control structure as a service to the organization. Its objectively examines, evaluates and reports as the adequacy of internal control system as a contribution to the proper, economic, efficient and effective use of resources". Minicamp (1996).

From the above definitions it is evident that audit is a systematic process (not a random, indefinite practice) objectively used in obtaining and evaluating audit evidence. This implies that the auditor must be independent and unrestricted in obtaining information and be in position to form a reasonable and reliable opinion there-from. Moreover, opinion and conclusion must be based on confirmed evidence and not on some prejudices and assumptions (Anderson, 1998). The auditor is required to have knowledge of the philosophy and practice of auditing, and also to have some degree of training, experience and common knowledge. An independent auditor should have the ability to recognize indication of irregularities and to keep abreast of development in the prepared and presented financial statements. This will enable the users of financial statement for instance; shareholder, insurance brokers, bankers, auditory government authorities, and the public to be confident that the picture of the company given by the directors is true and fair.

For this reason, CAMA (2004) has required the Directors to obtain a second opinion from an outside expert (Professional/External auditor) who is independent of the company's management and represents the interest of the stakeholders. Credibility is given to the financial statements by this auditor's professional opinion owing to his/her training, experiences, integrity, professional judgment, and most importantly, independence. The external auditor report to shareholders on whose behalf he is acting. However, the internal control and internal check systems must be supervised by someone inside the organization so as to make the work of the external auditor easier. This person is the internal auditor.

\subsection{Classes of Audit}

Audit is mainly of two types namely, internal and external Audit. While Internal Audit dealings and operations are within the organization guide and are part of the control system, external audit is that which is invited from outside the originations. Section 57 (5) of CAMA (2004), pointed out that someone need to cross check financial transaction and report on whether the organization's transactions have been carefully and rightfully done in accordance with the standard stated. He reports his finding to the shareholders at the Annual General Meeting (AGM). The External Auditor is the Auditor which CAMA (2004) is really concerned with.

\subsection{Who is the Internal Auditor?}

Very large organizations and some small ones have found a need for an internal audit in addition to an external audit. Internal auditors are employees of the organization and work exclusively for the organization. Their functions partly overlap those of external auditors and in part quite different. The exact tasks of external auditors are either stated by law or contained in a letter of engagement. The functions (which are rarely precisely laid down) of internal auditors are determined by the management and vary greatly from organization to organization. The internal auditor can be seen as the representative of the Board of Directors within the organization. Holmes and Overnuye (1990) sees Internal auditing as that type of audit, which is carried out by an auditor who is an employee of the organization, which he is auditing and his report is for his employer. His position in the organization is particularly important for it's closely bound up with internal control system of the enterprise.

Nagy and Cenker (2002), examined the modern meaning of internal auditing as an "independent, objective assurance and consulting activity designed to add values and improve an organization's operation". While there are differences in opinion on objectives, there is the believed that there has been a definite shift in the overall scope of internal audit. Though belief in the modern concept about internal auditing is highly held, a warning is communicated about the complete abandonment of the traditional role was communicated. In short, the internal auditor is in charge of internal auditing. Internal auditing can be defined as an independent appraisal of activities within an organization for the review of operations as a service to management (Millichamp, 1996). It is a managerial control which functions by determining and appraising the usefulness and efficiency of other controls. 
One of the characteristics of internal auditing is that independent personnel carry out internal auditing. That is to say although the internal auditor is not independent of management who is appointed and control by them, but independent in that they report to the Director of finance or the chief accountant. Internal auditors may find themselves in a position of needing to criticize the work of their immediate supervisors, which is clearly unsatisfactory.

As an appraisal activity, their job is to appraise part of data processing. For example, a person who spent his time checking employee expense claims is not performing internal audit functions.

As a service to management they require that its policies are fulfilled, and that the information that management requires to manage very effectively is reliable and complete. He also ensures that the organization's asset is safeguarded.

\subsubsection{The Role of Internal Auditors}

The internal auditor helps in managing internal control. The role of management is to adopt sound accounting practice for maintaining adequate and effective system of accounts, for safeguarding assets and assuring sound system of internal controls for the preparation of financial statements. They render service to the management with regard to the management role.

Internal Check is another role of the internal auditor. The internal check is part of the internal control system because it is a check on the day-to-day operations (transactions) of the organization. Management because of their engagement may not be able to carry out this function effectively.

For reliance to be place on the audit department of an organization the effectiveness, competency and professional care of the internal auditor and the attitude of management toward internal control must be checked. In the case of carrying the role above, the internal auditor will find him/herself in the responsibilities of verifications (which will cover the verification of records and reports to ascertain their reliability with regards to financial operation), presentation and other significant information. Verifications should be made on assets and liabilities to ensure that they are correctly stated (Wolf, 1990). The internal control system should also be evaluated to ensure that they are adequate and operate as management expert. He will also have to prevent and detect fraud and other irregularities as this is the objective of internal control system. But in case these occur, the internal control system should be able to detect such manipulations. The degree of prevention and detection of fraud and error will determine the efficiency of the internal control system and the degree of reliance to be placed on it.

\subsubsection{Responsibilities and Authorities of the Internal Auditor}

As earlier mentioned, Internal Auditors are employees of the organization and work exclusively for the organization. The responsibilities of external auditors are either laid down by statue or embodied in a letter of engagement. The responsibilities of internal auditors however, are determined by management and vary greatly from organization to organization. The general responsibilities of internal auditors (which are rarely precisely laid down) are clearly stipulated in auditing guidelines issued in June, 1990 (Holmes and Overnuye, 1990). In this vein Millichap (1996) provides three functional areas of internal audit thus:

Firstly, an appraisal of functions of personnel in the organization. The job of an internal auditor is to appraise the activities of others, not to perform a specific part of data processing, for example, a person who spent his time checking employee's expense reviewing the system for checking employee's expense may well be performing an internal audit function.

Secondly, it serves as a service to the organization. The management in order to promote viability, reliability, accountability and authenticity requires that its policies are fulfilled, the information it requires to manage effectively is reliable and comprehensively complete, the organization's assets are safeguarded, the internal control system is well designed and the internal control system works in practice.

Other responsibilities of internal auditors include being concerned with the implementation of social responsibility policies adopted by the management. Also being concerned with the response of the internal control system to errors and required changes to prevent errors. He is also concerned with the response of the internal control system to external stimulation. The world does not stand still and the internal control system must continually change. He also audits the information given to management particularly interim accounts and management accounting reports.

\subsubsection{The Position of the Internal Auditor in Management}

The position of internal auditor in management or any organizational structure determines his power and authority. This position may vary from organization to organization. For instance, most organizations maintain a structure in which the internal auditor is expected to report directly to the Managing Director. This kind of structure places the internal auditor in the same rank and level with General Manager (Finance) and 
General Manager (production). The internal auditors under this structure has the necessary authority to require all department in the organization to supply him with adequate information relating to the affairs of their respective divisions (Wolf, 1990)

By contrast, it would be completely unsatisfactory to have the internal auditor operating under the jurisdiction of the Finance Manager or Chief Accountant. The internal auditor would then be placed in the position of having to receive line functions under the control of an immediate superior, i.e. Finance Manager or Chief Accountant and he might consequently fell under pressure to soften findings should they be critical.

\subsection{Who is the External Auditor?}

This individual is in charge of auditing the organization's books as stipulated by CAMA, 2004. Section 363 of CAMA, 2004 defines the role of an external auditor. He is a statutory auditor appointed to give an independent report to shareholders on each set of accounts laid before them at the Annual General Meeting (AGM) as to whether the balance sheet shows the true and fair view of the state of affairs of the company as at the balance sheet date including its profit and loss account and to ensure compliance with CAMA, 2004 and other relevant provisions.

The management on behalf of the shareholders prepares this set of financial statements. It is therefore, assumed that the appointed auditor is for the interest of the shareholders and other interested parties. If the users of the financial statements are to believed and relied on auditors opinion, it is essential that the auditor is independent of the entity, its management, and other parties. The other role of an external auditor, which appears secondary in nature, is to detect fraud and errors and include such in his report (Anderson, 1998).

\subsubsection{External audit problems}

Poorly staffed internal audit inspection department and resultant inadequate operational coverage is a major problem. Also Clients may mount pressure on auditors to cover up any irregularity. There is also the problem of inadequate and inefficient internal control system. Lack of cooperation from clients, staff in different departments or sections also hampers the work of external auditors. Finally and most importantly is Client's inability to pay Audit's fees.

\subsection{Qualities of an auditor (Internal or External)}

The following are some of the qualities of Auditors as stated by Holmes and Overnuge (1990). As one of the principal objectives an auditor is to ascertain whether the generally accepted principles of accounting have been adhered to in the issuing of accounting directives and that these directives have been duly observed. It follows that the auditor should have a thorough knowledge, both of theoretical and practical accounting and also of the internal regulation governing the accounting procedure in operation.

Constructive curiosity should be another quality of an auditor. This means a desire to know and understand something in one's sense as against mere inquisitiveness. The auditor must be interested in his own work and also in the work of the organization which he serves.

Auditors should also have analytical abilities. By analytical ability it means the audit must be able to appraise the problem or situation he is examining. Added to this is the quality of Constructive Ability. Analytical ability is not sufficient; it must be buttressed with constructive ability. This has to do with the development of the auditor's imagination so that remedies may be suggested for weaknesses. The internal auditor, after careful consideration of all aspects of the situation he examines, recommends a specific remedy for those weaknesses.

Intellectual intelligence is another quality they should possess. In the performance of their duties, the auditor must be independent, i.e., he must approach his work objectively without bias and free from any prejudices or learning which might influence his judgment. The audit department would be competent when it is staffed with people who are well trained and can assess, evaluate and recommend measures to improve the internal control system. Besides professional qualification, the internal auditor must be further developed by sending them to seminars, workshops and conferences to acquire new methods of performing their functions. The auditor should possess humanistic, linguistic, communicative, literary and intellectual gains that will enable him carry out his work efficiently.

Scepticism and Inquisitiveness (curiosity) must be part of an auditor's outlook. These two qualities help an auditor to function well. They are somewhat akin in that an auditor should be sceptical but not suspicious. If too trusting, the auditor may miss important warning signals and if lacking in curiosity he or she may never pursue cases that might lead to greater understanding of an organization's business.

Good communication and leadership ability are also necessary for a professional auditor. He must be able to write intelligent and constructive reports on audit finding and recommendations. He should have a capacity for orderly written or spoken word. The auditor must possess the ability to achieve cooperation of staff 
at all levels and to report clearly and concisely to his client on accounting and administrative matters. He must of necessity possess dexterity as a leader to gain their trust, respect and confidence of the working group.

Self Confidence is another quality of a good auditor. A desirable sense is essential; not arrogance, or smugness. An auditor will be reluctant to raise sensitive questions with the management or to confront them with unpalatable findings, or will do so in such a hesitant or apologetic manner as to be about self-defeating.

Assertiveness and Fairness should also be possessed by an auditor. This flow naturally from selfconfidence since the self-confident person will not be reluctant to state a case when required to do so in spite of the possibility of encountering a negative reaction. This, of course, is what most people hope for in all of their relationships with others, but it is an especially important trait for an auditor to possess.

Integrity and High Ethical Standards are almost inseparable concepts that an auditor should possessed. They both involve honesty and right conduct. Integrity is the sine qua non auditing. The auditor's real success lies on how effectively he discharges his public trust, and how conscientiously he serves the public interest.

\subsection{Internal and external auditors compared and contrasted}

Both are interested in the following: an effective system of internal control, continuous effective operation of such system, adequate management information flow, assets safeguarding and adequate accounting system (for example to comply with the CAMA, 2004). Also both of them have common interest of ascertaining that there is an effective check to prevent or detect errors and fraud in an organization and that the accounting system is prepared to provide the information necessary for preparing financial statements (Kwame, 1999). Moreover, both adopt similar methods in the examination of the system of internal control for both soundness in principle and effectiveness in operation, checking of accounts, and verification of assets and liabilities. Although both have a common interest in certain matters as mentioned above the two types of auditors differ in the aspects of scope, objective, responsibility, approach, independence, remuneration and qualification. The management determines internal audit work but statutes lay down the external auditor's work. The internal auditor may have a number of aims in his work including an appraisal of the efficiency of the internal control system and the Information Technology. The external auditors are interested primarily in the true and fairness of the accounts (Kwame, 1999). The internal auditor is answerable only to management. The external auditor is accountable to shareholders and debatably to society in general. Both are of course accountable to their integrities and the ethical standards of their professional bodies.

The approach of the internal auditor is the review of all information and ensure that the accounting system are efficient accurate and discloses material facts, but the external auditor is primarily interested in the truth and fairness of the accounts prepared by management. By virtue of appointment the internal auditor cannot be independent of the management that employed him; whereas an external auditor should be independent of the management (Anderson, 1998). The internal auditor is responsible to the management that employed him while the external auditor is responsible to the shareholders. This makes him liable for any professional opinion arrived at. The remuneration of the internal auditor is fixed by the management who employs him and is expected to report back to them. Whereas the external auditor whether appointed by the shareholder at the AGM or on the approval of the management is expected to report to the shareholders. In terms of qualification not all accountants are external auditors. There is minimum academic and professional qualification expected from external auditors. The requirement ranges from statutory to professional pronouncement.

\subsection{Empirical Results of the Relationship between Internal and External Auditors}

Researches on the relationship between internal and external auditors are saturated. Many researchers have explore the subject matter from different perspective with different outcomes and results. Brody, Golen, and Phitip (1998), indicate that the external auditors pays more attention to the quality difference in the internal audit department. Moreover, individual characteristics of auditors has greater influence over their judgments. A look at the voluntary demand for audit services found no explanation for the demand for internal audit. There was also an inverse relationship between internal and external auditing in the family business environment (Carey, Simnett \& Tanewski, 1999). Responses from their studies show that external auditor's views internal auditor more as substitutes rather than contemporary (Carey et al., 1999).

Desai, Roberts and Srivastava (2010) looked at the external auditor's evaluation of strength of internal auditor functions. Their work discovered that the extent of work to be carried out by an external auditor is determined by the strength of internal audit function and the amount of legal and regulatory cost to be incurred by the external auditor. Examining the effects of internal audit sourcing arrangement on external auditor's reliance on internal auditor, Glover, Prawitt and Wood (2007) found out that reliance is less when considering subjective tasks as against objective tasks. Furthermore, indirect sourcing arrangements depending on the external auditor's perceptions of the internal auditor's objectivity. The impact of external auditor's outsourcing 
and inclusiveness on consulting rely heavily on the internal auditor's work (Munro \& Stewart, 2010). The emphasis is on how the external auditor could rely on the internal auditor for quality work and assistant. Involvement in consultation with internal auditor's impacts heavily on reliance work and using internal auditors as auditors. Internal auditors are needed more when it comes to substantive testing and internal control evaluation.

An investigations of the degree of reliance on the role of internal auditors by external auditors was carried out by Suwaidan and Qasim (2010). Using cross-sectional multiple regression in analysing the impact, it was discovered that objectivity, competence and performance are the important factors determining reliance on internal auditors. Wood (2004), stated that due to the growth in the responsibilities of the external auditor, the internal auditor could add value to organizations' operations by improving coordination with the external auditor. In a study that targets how value could be added by the internal auditor through coordination with the external auditor, the result of Wood (2004) was that internal auditors stands a good chance to help improve investor's confidence in coordination with external auditor which is achieved by learning professional standards and increasing communication and instigating trainings to mention but few.

\section{METHODOLOGY}

The method of collecting data used in this research includes both primary and secondary. The primary data were sourced from a face-to-face interview with the proprietors of some Chartered Accounting firms. Documents used by the writer, which formed the secondary data were in the form of text books and other library facilities which helped greatly in compiling this paper. Thus the questions contained in the interview schedule were such that required an exact or near uniform answer from the respondent. The questions were grouped into parts in terms of the relationship between the auditors (Internal and External). They range from: immediately after the appointment of the External Auditor, when discharging his duties and responsibilities, cooperation from Internal Auditors, awareness of the contents of the external auditor's report, his response to the content of the report, social relationship, and respondents general view. As a result of this, analysis of data hence shown in detailed in "Discussion of Result" is a reflection of data collected. Analysis made was through content analysis.

\section{1}

\section{DISCUSSION OF RESULTS}

The Trust on External Auditors: Public vs. Private

The relationship between the internal auditor and a newly appointed external auditor depends on the type of the organization, i.e. whether it is private or public. Majority of Chartered Accountants agreed that in the private sector the internal auditors are normally happy when an external auditor is appointed (provided he did not come to witch hunt) because they see him/her as partners in progress. In government organizations, the appointment of an external auditor is politically sensitive as such the external auditor is frustrated from the onset. However, there is nothing they could do about his appointment but to wait for its expiration. The implication here is that the internal auditor in the private sector trusts the external auditor more compared to his counterpart in the public sector. This will enable the external auditor to work more effectively and efficiently in the private sector than in the public sector.

\subsection{The Extent of Cooperation by Internal Auditors}

The internal auditor is bound to cooperate with the external auditor because that is a requirement of the law (CAMA, 2004). Over 90\% of respondents attest that internal auditors subject themselves to their questioning because they (internal auditors) are seen as part and parcel of management. Management (including the internal auditor) is also expected to supply any information requested by the external auditor. The external auditor should under no circumstances however, accept the work of the internal auditor because at the end of the day he (the external auditor) will have to be held fully responsible for his report. This indicates that whether they like it or not the internal auditor must cooperate with the external auditors.

\subsection{Audit Test and Assessment}

Majority of the respondents agreed that audit test and assessment of internal control systems should be carried out by the external auditor and must not in any case rely on the job of the internal auditor. This is to show how strong the internal control system design and operated by management is.

\subsection{Sabotage by Internal Auditors}

Since snubbing the external auditor is impossible in public organizations, some internal auditors resort to sabotaging his work. For instance information could be hidden from him and very good excuses given for that. Experience from external auditors reveal that some records could be hidden and the staff may report that 
the person in charge of them have either resigned or died. This loss will affect the result of tests carried on records.

\subsection{Accuracy and Consistency of the Reports}

All the respondents agreed that the content of the external auditors report is not hidden from the internal auditor. Because any obstacle or irregularities discovered must be cleared by the internal auditor. In this case massive cooperation from the internal auditor is gained if he discovered that the report will be qualified. This is because the external auditors report is in effect an assessment of the internal auditor's efficiency. Therefore once there is a problem he assists greatly in detecting the cause of that problem. Thus cooperation comes more from the internal auditor when reports are to be qualified.

\subsection{Level of Interaction}

Socially, internal auditors interact well with external auditors as discovered from the interview; except if by nature they are introvert. This is healthy for the entire audit process.

\subsection{Effect of Report on Management}

Results from this research shows that generally where the job of the external auditor implicates the organization's management, it implies the internal auditor have not done his job or is inefficient. In the public sector, this report is taken to the Board of the organization which sends it to the Auditor-General's office which in turn sends the report to the Public Accounts Committee of the legislature for action. This fear is what in the public sector always forced cooperation from the internal auditor.

\subsection{Summary}

\section{CONCLUSION AND RECOMMENDATIONS}

Auditors whether internal or external are expected to perform audit functions. While the internal auditor is an employee of the organization the external auditor is completely independent of the organization he audits. The rules and regulation governing the duties of the internal auditor are contained in the organizations Article of Association and his appointment letter, while those of the external auditor are govern by law (CAMA, 2004). For this reason though they are similar in some respect there are also some striking differences between them. This paper has tried to examine the relationship between the internal and the external auditor. It was discovered that the relationship in the private sector is more cordial and trust worthy than in the public sector where external auditors are regarded as agents of the government of the day.

\subsection{Findings and Recommendations}

Our discovery showed that in the private sector external auditors are trusted more by their internal counterpart than in the public sector except where the internal auditor is suspected of witch hunting. Also whether they like it or not internal auditors must cooperate with external auditors especially if they don't want the report of the external auditor to be qualified.

It is therefore advisable that for proper cooperation between the two, internal auditors should understand that the external auditor is there to do his job and should not be seen as an agent of a third party or a witch-hunter. The internal auditor should also endeavour to do his job honestly and efficiently in accordance with the ethics of his profession, the rules and regulation governing his job and in line with the basic principles and conventions in financial reporting so as to ease the work of the external auditor and establish a good working relationship.

\section{REFERENCES}

[1] Ademola, A. (1984). Management advisory services and audit independence: a cost-benefits approach. Lagos, Nigeria.

[2] Anao, A. R. (1989). Introduction to Financial Accounting. Longman Nigeria Limited.

[3] Anderson, R. J. (1998. The external auditor: concept and techniques. Pitman publishers, Toronto, Canada.

[4] Brody, R. G., Golen, S. P. \& Phitip, M. J. (1998, June). Empirical investigation of the interface between internal and external auditors. Accounting and Business Research, 28(3); 160-171. https://www.researchgate.net/publication/223435256

[5] Carey, P., Simnett, R. \& Tanewski, G. (1999, October). Demand for internal and external auditing by family businesses. Auditing. A Journal of Practice \& Theory, vol. 19 supplement 2000. https://www.researchgate.net/publication/228320425

[6] Companies and Allied Act (CAMA) 1990 (2004 as codified). Part XI Chapter 2 Section 357-369. 
[7] Dandago, K. I. (1999). Auditing in Nigeria: a comprehensive text. Adamu Joji Publishers, Kano.

[8] Desai, V., Roberts, R. W. \& Srivastava, R. (2010). An analytical model for external auditor evaluation of the internal audit function using belief functions. Contemporary Accounting Research. American Accounting Association Meeting, and research workshops at CUNY Baruch, the University of Central Florida, Wilfred Laurier University, and York University,

[9] Glover, S. M., Prawitt, D. F. \& Wood, D. A. (2007, April). Internal audit sourcing arrangement and the external auditor's reliance decision. Contemporary Accounting Research. https://www.researchgate.net/publication/228307310

[10] Haron, H. (2004). The reliance of external auditors on internal auditors. Managerial Auditing Journal, 19(9); $1148-1159$.

[11] Holmes, A. and Overnuye, W. (1990). Auditing Principles and Procedure. Home Wood Richard D. Irvin Inc. London.

[12] Kwame, G. (1999). An International Guide to Auditing. Graham Publications Ltd. London.

[13] Mike Ukueje and Co. (2011); Ibrahim Taiwo Road, Kano.

[14] Millichap, A. H. (1993): Auditing: an instructional manual for accounting students. $6^{\text {th }}$ Edition. DP publisher Ltd. London.

[15] Munro, L. A. \& Stewart, J. D. (2009). External auditors' reliance on internal audit: the impact of sourcing arrangements and consulting activities. Accounting and Finance Association of Australia and New Zealand. QUT Digital Repository. https://eprints.qut.edu.au/

[16] Nagy, A. L. \& Cenker, W. J. (2002). An assessment of the newly define internal audit function. Managerial Auditing Journal, 17(3); $130-137$

[17] Sheka, G. I. (2009). Nigeria and the Global Financial Crisis: What Needs to Be Done? A paper presented at Gombe State University. Suwaidan, M. S. \& Qasim, A. (2010, June). External auditors' reliance on internal auditors and its impact on audit fees: an empirical investigation. Managerial Auditing Journal, 25(6); 509-525. https://www.researchgate.net/publicagtion/227429887

[18] Wolf E, (1990). Auditing Today. HFI publisher's ltd. London.

[19] Wood, D. A. (2004). Increasing value through internal and external auditor coordination. The IIA Research Foundation. 